COMMENTARY

\title{
SURVIVING OVERLAPPING PRECARITY IN A \\ 'GIGANTIC HELLHOLE': A CASE STUDY OF VENEZUELAN LGBTQI+ ASYLUM SEEKERS AND UNDOCUMENTED MIGRANTS IN BRAZIL AMID COVID-19
}

\author{
YvonNe Su, ${ }^{*}$ TyLER VALIQUETTE ${ }^{* *}$ AND YURIKO COWPER-SMITH***
}

\section{TABLE OF CONTENTS}

I Introduction

II Lack of Livelihood, Mounting Mental Health Issues and Uncertain Status ......... 157

III Undocumented Migrants, Trochas and Precarious Belonging.

IV Recommendations from LGBTQI+ Asylum Seekers and Undocumented Migrants

A Better Supporting Refugees During the Pandemic: What Can the Humanitarian Sector and the Government Do to Improve their Responses?

B Lessons for the Future: Access to Documentation and Healthcare .......... 160

V The Link between Being Undocumented and Statelessness ................................. 160

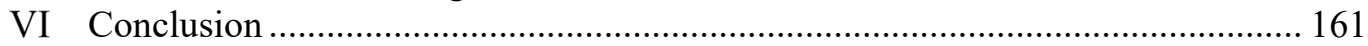

\section{INTRODUCTION}

As COVID-19 infection rates grew exponentially in Latin America, countries closed their borders in an attempt to stop the virus. But such measures have put migrants, asylum seekers and other forcibly displaced persons at more risk. For highly precarious groups, such as Venezuelan migrants and asylum seekers in Brazil, who were already facing a multitude of challenges before the pandemic, COVID-19 is multiplying the threats. ${ }^{1}$

The closed borders have been a convenient cover for a growing humanitarian crisis as people are forced to move 'illegally' through dangerous paths. ${ }^{2}$ As migration continues, the situation along the Brazilian-Venezuelan border has

* Dr Yvonne Su is an assistant professor in the Department of Equity Studies at York University. She researches forced migration, refugee protection and inequality.

** Tyler Valiquette is based in Brasilia and holds a MA in Political Science from the University of Guelph. He is a researcher on LGBTQI+ and refugee rights focusing on local, national and international responses.

*** Dr Yuriko Cowper-Smith holds a PhD in Political Science from the University of Guelph. She researches diaspora-led social movements, forced migration, statelessness, and genocide.

1 Yvonne Su, Yuriko Cowper-Smith and Tyler Valiquette, 'LGBTQI+ Populations Face Unique Challenges During Pandemic', Policy Options (online, 24 Jul 2020)

$<$ https://policyoptions.irpp.org/magazines/july-2020/lgbtqi-populations-face-uniquechallenges-during-pandemic/?fbclid=IwAR3m5tUjNoqNjBafLMttQHtE2aCBw_goQIqkpxv8NyqHkjN-T_3Yd9jzKs>.

2 Interview with Emilio Felix (Tyler Valiquette, Zoom, 5 March 2021). 
demonstrated that closed borders are not a good mechanism to prevent crossings. Instead, these border closures are violating the principle of non-refoulement the obligation under international law not to send people back to face human rights abuse - and creating more insecurity for persons in need of international protection.

Since 2015, more than 5 million people ${ }^{3}$ have fled Venezuela and 264,000 people have applied for asylum in Brazil. ${ }^{4}$ The people who come to Brazil often travel to Manaus, one of the largest economic centres, which is located near the border. Manaus is one of the world's COVID-19 hotspots and the birthplace of the Brazil variant. In April 2020, the first wave devastated the city and bodies were buried in mass graves. ${ }^{5}$ The rate of infection was so high that Manaus was believed to be the first city in the world to reach herd immunity, but any hope that the pandemic was over was quickly quashed when the second wave collapsed the city's health care system in January 2021. The hospitals were so inundated that they ran out of oxygen and patients had to resort to sourcing their own oxygen tanks to survive. ${ }^{6}$

On 24 March 2021, as the World Health Organization stated that Brazil's COVID-19 situation was affecting its neighbours, the former president of Colombia, Ernesto Samper, tweeted that 'Bolsonaro has managed to turn Brazil into a gigantic hellhole'. ${ }^{7}$ At this time, Brazil was leading in the number of new COVID-19 cases and deaths per day. ${ }^{8}$ As of 20 June 2021, the country has reported almost 18 million cases of COVID-19 and over 500,000 people have died. ${ }^{9}$

This failure to respond is a result of President Jair Bolsonaro's continual denial of the pandemic. The President, a COVID-19 survivor himself, has called the virus

3 'IOM and UNHCR Welcome Donor Pledges for Venezuelan Refugees and Migrants' IOM (News Report, 26 May 2020) < https://www.iom.int/news/iom-and-unhcr-welcome-donorpledges-venezuelan-refugees-and-migrants $>$.

4 Anthony Boadle, 'U.S. Backs Program to Settle Venezuelan Migrants in Brazil', The National Post (online, 28 Jan 2020) <https://nationalpost.com/pmn/news-pmn/politics-news-pmn/u-sbacks-program-to-settle-venezuelan-migrants-in-brazil $>$.

5 Tom Phillips and Fabiano Maisonnave, “Utter disaster": Manaus Fills Mass Graves as Covid-19 Hits the Amazo", The Guardian (online, 30 Apr 2020)

$<$ https://www.theguardian.com/world/2020/apr/30/brazil-manaus-coronavirus-massgraves $>$.

6 Júlia Ledur, 'The Arduous Path for Oxygen to Reach the Sick in One of Brazil's Most Remote Regions', The Washington Post (online, 11 Feb 2020)

$<$ https://www.washingtonpost.com/graphics/2021/world/manaus-amazonas-coronavirusmedical-oxygen-shortage/>.

7 Tom Phillips, Uki Goni and Joe Parkin Daniels, "“The Heart of Darkness": Neighbors Shun Brazil Over Covid Response', The Guardian (online, 30 Mar 2021)

$<$ https://www.theguardian.com/global-development/2021/mar/30/neighbors-shun-brazilcovid-response-bolsonaro>.

8 Ernesto Londoño and Letícia Casado, 'A Collapse Foretold: How Brazil's COVID-19 Outbreak Overwhelmed Hospitals', The New York Times (online, 31 May 2021) <https://www.nytimes.com/2021/03/27/world/americas/virus-brazil-bolsonaro.html>.

9 Reed Abelson, 'Brazil's reported one of the highest Covid death tolls in the world.', The New York Times (online, 28 June 2021)

$<$ https://www.nytimes.com/2021/06/20/health/brazil-deathscovid.html?searchResultPosition $=2>$. 
a 'measly cold' 10 and said masks are 'for fairies', a common homophobic slur. 11 Downplaying the severity of the pandemic, the openly homophobic president has also called on Brazilians to stop being a 'country of sissies', using the Portuguese homophobic slur 'maricas'. ${ }^{12}$ Under previous leadership, Brazil gained global praise for their handling of health crises including AIDS and the Zika virus, but the Bolsonaro Government's lack of response has harmed the country's ability to cope. ${ }^{13}$

From March to April 2021, our research team surveyed 19 Venezuelan LGBTQI+ asylum seekers and undocumented migrants in Manaus and Brasilia. These are Venezuelan citizens who have crossed the border to Brazil in the last two years. Sixteen of the respondents are asylum seekers and three are undocumented migrants who do not have any status in the country, as the asylum process has been halted during the COVID-19 pandemic and the border is technically closed. Our preliminary research indicates that, during the pandemic, they are: 1) unable to meet their basic needs due to a lack of livelihood, 2) struggling with increased mental health issues and 3) uncertain about their legal status. Our respondents described the Brazilian Government's COVID-19 response as inadequate with several respondents being reluctant to criticise the Government. In addition, our conversations with three trans women who crossed the border during the second wave of the pandemic gave us insight into the challenges undocumented migrants face in crossing borders during a pandemic. Ultimately, we argue that the lives of Venezuelan LGBTQI+ asylum seekers and undocumented migrants in Brazil have been made particularly vulnerable due to 'politically produced precarity' in a situation of 'overlapping precarity' during the pandemic. ${ }^{14}$

\section{LACK OF LiVELIHOOD, MOUNTING MENTAL HEALTH ISSUES AND UNCERTAIN STATUS}

In March 2020, quarantine measures banned the informal income sources of LGBTQI+ asylum seekers, such as sex work or selling items on the streets. ${ }^{15}$ Of the 19 asylum seekers and undocumented migrants interviewed, 15 reported that COVID-19 has made their livelihood unsafe, caused them to risk their lives to make a living or has eliminated their income. As a young bisexual male asylum seeker shared: 'Because of the restrictions, I can't get out of my house to work'.

10 Ernesto Londoño, Manuela Andreoni and Letícia Casado, 'Bolsonaro, Isolated and Defiant, Dismisses Coronavirus Threat to Brazil', The New York Times (online, 18 June 2020) $<$ https://www.nytimes.com/2020/04/01/world/americas/brazil-bolsonaro-coronavirus.html $>$.

11 Tom Phillips, 'Brazil: Bolsonaro Reportedly Uses Homophobic Slur to Mock Masks', The Guardian (online, 8 Jul 2020) < https://www.theguardian.com/world/2020/jul/08/bolsonaromasks-slur-brazil-coronavirus $>$.

12 Tom Phillips, 'Brazil's Fearful LGBT Community Prepares for a "Proud Homophobe", The Guardian (online, 27 Oct 2018) <https:/www.theguardian.com/world/2018/oct/27/dispatchsao-paulo-jair-bolsonaro-victory-lgbt-community-fear>; Antonia Noori Farzan and Miriam Berger, 'Bolsonaro Says Brazilians Must Not Be Sissies About Coronavirus, as "All of us are Going to Die One Day", The Washington Post (online, 12 Nov 2020)

$<$ https://www.washingtonpost.com/world/2020/11/11/bolsonaro-coronavirus-brazilquotes/>.

13 Londoño and Casado (n 8).

14 Elena Fiddian-Qasmiyeh, 'Responding to Precarity: Beddawi Camp in the Era of COVID19' (2020) 49(4) Journal of Palestine Studies 27, 28.

15 ibid 8. Whilst the measures themselves did not specifically target LGBT asylum seekers, the measures that were enacted banned specific types of labour which impacted the labour typically performed by LGBT asylum seekers. 
A consequence of the inability to work is a lack of funds to meet their basic needs. Citing a lack of work and increased food prices, 14 respondents said they did not have enough food to eat every day.

On 7 April 2020, the Brazilian Government created an emergency benefit of BRL600 (USD120) for unemployed people, self-employed people with low income, informal workers and impoverished families for a period of three months. Recently, the benefit was extended but reduced to BRL150 (USD27). ${ }^{16}$ Only four of the respondents said that they received it. Several said that they did not have the correct documentation or did not understand how to obtain it. Three respondents could not apply for the benefit because they are undocumented.

When asked '[b]efore COVID-19, how often did you suffer from struggles with anxiety, lack of sleep, and/or depression?', the majority of respondents answered '[n]ever' and no one reported '[d]aily' (see Table 1). However, when asked about mental health during the pandemic, the numbers increased, with six respondents noting they suffer mental health issues on a daily basis. A gay male asylum seeker in his 50s shared: 'I was depressed and the willingness to make a living went down because of all of the negative things that I saw around me all the time.' His response sheds light on the overlapping precarity that he, and others in similar situations, are facing and how his poor mental health and the lack of jobs combined with the general low morale of the pandemic-stricken world has made his daily life increasingly difficult.

Table 1: The frequency of mental health stressors cited by asylum seekers and undocumented migrants:

\begin{tabular}{|l|l|l|}
\hline $\begin{array}{l}\text { Frequency of mental health } \\
\text { stressors }\end{array}$ & $\begin{array}{l}\text { Before COVID-19 } \\
(\mathrm{n}=19)\end{array}$ & $\begin{array}{l}\text { During COVID-19 } \\
(\mathrm{n}=19)\end{array}$ \\
\hline Never & 12 & 6 \\
\hline Yearly & 1 & 0 \\
\hline Monthly & 3 & 1 \\
\hline Weekly & 3 & 6 \\
\hline Daily & 0 & 6 \\
\hline
\end{tabular}

Lastly, with the asylum process halted in Brazil, many unprocessed asylum seekers and displaced peoples have become undocumented migrants. ${ }^{17}$ An asylum seeker's status is only valid for one year, after which extensions are required. These extensions are obtained through the Brazilian Federal Police, whose services are unavailable during the pandemic. ${ }^{18}$ Only applicants who understand Portuguese can access the Federal Police's website to learn how to legally remain in Brazil until September 2021. This information is not clearly communicated to many asylum seekers, including those who were interviewed. They discussed the confusion with their documentation and status, and are actively avoiding the police because of their expired documents.

16 Patricia Martuscelli, 'How are Refugees Affected by Brazilian Responses to COVID-19?' (2020) 54(5) Brazilian Journal of Public Administration 1446, 1453 ('Refugees Affected'); Ana Ferraz 'Covid Emergency Aid to be Extended for Two Months' The Brazilian Report (online, 8 June 2021) <https://brazilian.report/liveblog/2021/06/08/covid-emergency-aidextended-two-months $/>$.

17 Patricia Martuscelli, 'How Are Forcibly Displaced People Affected by the COVID-19 Pandemic Outbreak? Evidence from Brazil' [2021] American Behavioural Scientist 1, 6, 13.

18 Interview with Emilio Felix (Tyler Valiquette, Zoom, 5 March 2021). 


\section{Undocumented MigRants, Trochas AND PRECARIOUS BELONGING}

Before the pandemic, migrants and forcibly displaced Venezuelans were already known to take irregular routes into Brazil. According to a December 2020 Situation Report by the Organization of American States (OAS), there are an estimated 500-700 Venezuelans leaving the country each day through trochas (irregular paths) or dangerous sea routes. ${ }^{19}$ These paths often leave them vulnerable to traffickers, smugglers or armed groups. ${ }^{20}$ With closed borders, Venezuelan migrants have reported that their migratory routes are more dangerous. ${ }^{21}$

Our surveys with three young trans women who crossed the Brazilian border irregularly in early 2021 have revealed that the situation in Venezuela was so dire that they were forced to flee amid a pandemic. They came through a trocha and hitchhiked and walked their way to Manaus. Since they are undocumented, they do not qualify for the Government's emergency benefit. They arrived at Casa Miga, the only LGBTQI+ refugee shelter in Latin America. But due to some conflicts, the women were asked to leave Casa Miga in April 2021. Thus, despite finding a shelter that is meant to be a safe space, the situation of overlapping precarity pushed these trans women to rule breaking, which led them to be forcibly displaced once again.

\section{RECOMMENDATIONS FROM LGBTQI+ ASYLUM SEEKERS AND UNDOCUMENTED MIGRANTS}

The majority of respondents believed the Brazilian Government's approach was inadequate, very inadequate, or completely inadequate (see Table 2). The following section highlights the respondents' suggestions for improving the lives of refugees and asylum seekers during the pandemic.

Table 2: How would you rate the Brazilian Government response to the pandemic?

\begin{tabular}{|l|l|}
\hline Response & Number of Respondents $(\mathrm{n}=19)$ \\
\hline Completely inadequate & 3 \\
\hline Very Inadequate & 2 \\
\hline Inadequate & 5 \\
\hline Adequate & 4 \\
\hline Perfectly adequate & 3 \\
\hline Prefer Not to Answer & 2 \\
\hline
\end{tabular}

19 'Situation Report December 2020: Venezuelan Migration and Refugee Crisis', Organization of American States (Report December 2020) 2 $<$ https://reliefweb.int/sites/reliefweb.int/files/resources/OAS_Dic20-crisis-of-Venezuelanmigrants-and-refugees-situation-report.pdf $>$ ('Organization of American States').

20 ibid 3; Marta Martinez, 'Women Fleeing Venezuela are Being Targeted for Abuse Amid Pandemic Border Closures', CNN (online, 22 Nov 2020)

$<$ http://www.cnn.com/2020/11/22/americas/colombia-venezuela-border-womenintl/index.html?fbclid=IwAR02xpjom_Yfxnq9XSEaZXpeUaeox-

FX1yYGZyFGaVNDHeSfdPaQTV_sfEY>.

21 John Costa do Santos and Thiago Riberio Costa, 'Gender and COVID-19 in the Context of the Refugee and Migrant Population in the City of Manaus-Amazonas (Gênero e Covid-19 no Contexto da População de Refugiados e Migrantes na Cidade de Manaus-Amazonas)' (2020) 11(4) Mundo Amazónico 62, 65; Manuel Rueda, 'Venezuelans Brave "Brutal" Migrant Route Made Tougher by Pandemic', $B B C$ (online, 7 Oct 2020) $<$ https://www.bbc.com/news/world-latin-america-54418542>; Martinez (n 20). 


\section{A Better Supporting Refugees During the Pandemic: What Can the \\ Humanitarian Sector and the Government Do to Improve their Responses?}

Direct recommendations from those populations most impacted by the pandemic are valuable insights. We asked respondents for their perspectives on how organisations and the Government can better support refugees and asylum seeker populations during the pandemic. The responses can be categorised around: 1) improved protections through the documentation process, 2) access to food and shelter and 3) access to health facilities. Most agreed that documentation could be faster and that there could be more shelters in the border states. Additionally, the respondents were concerned about the lack of public health measures and educational campaigns about preventing the spread of the virus, as well as inadequate access to COVID-19 testing and hygiene products. ${ }^{22}$

On improving the Government's response, participants requested 1) increased protections through documentation, 2) access to skill and language training, 3) increased livelihood opportunities and 4) greater access to healthcare. A gay asylum seeker in his 20 s or 30 s stated that the Government needs to 'offer training and Portuguese courses'.

\section{B Lessons for the Future: Access to Documentation and Healthcare}

Refugees in Brazil have access to different rights according to specific Brazilian legislation. Asylum law (Law No 9,474) guarantees the right to documentation to refugees. ${ }^{23}$ Migration law (Law No 13,455) repudiates and prevents xenophobia, racism and any type of discrimination. ${ }^{24}$ Article 4 of migration law (Law No $13,455)$ guarantees all immigrants access to public services, health services and social assistance with no discrimination based on nationality and migratory status. ${ }^{25}$ Overall, the pandemic has restrained the services of the Federal Police, causing significant harm and confusion to the asylum seekers and undocumented migrants. ${ }^{26}$

Additionally, with closed pandemic borders, the Venezuelans that arrive in Brazil using trochas are undocumented. Without status, undocumented Venezuelans are forced into precarious labour and are more insecure. It is recommended that in addition to opening the border, new assistance facilities are introduced in border states where Venezuelan migrants are arriving through trochas so that they are able to become documented. ${ }^{27}$

\section{The LinK BETWEen BeING UNDOCUMENTED AND STATELESSNESS}

Related to the aforementioned section, we consider the possibility that being undocumented leads to statelessness. Statelessness is a unique phenomenon or process in which an individual never obtained or lost their citizenship and does not have a means of recourse to reinstate their citizenship. ${ }^{28}$ Statelessness often

22 Interview with Emilio Felix, Manager, Casa Miga (Tyler Valiquette, Zoom, 5 March 2021).

23 Law No 9,474 1997 (Brazil) art 6 (Asylum law).

24 Law No 13,445 2017 (Brazil) art 3(II) (Migration law).

25 ibid art 4(VIII).

26 Refugees Affected (n 16) 1452.

27 Organization of American States (n 19) 5.

28 'What is Statelessness?', UNHCR (Web Page) <https://www.unhcr.org/ibelong/wpcontent/uploads/UNHCR-Statelessness-2pager-ENG.pdf $>$. 
stems from discrimination based in law or is a product of state succession. ${ }^{29}$ Statelessness is categorically different from being undocumented. ${ }^{30}$ However, the UNHCR \#IBelong campaign further details that being undocumented, for instance, by virtue of no longer having access to one's birth certificate, or through circumstances of displacement, raises the risk of statelessness. ${ }^{31}$

Indeed, this was already the position of some children born to Venezuelan refugees in Colombia. ${ }^{32}$ Since producing birth certificates is often challenged by substantial bureaucratic hurdles when in displacement, the children of Venezuelan refugees can sometimes obtain neither Colombian identity documentation nor Venezuelan identity documentation. ${ }^{33}$ This may leave them in a situation of statelessness. With so many Venezuelan asylum seekers in Brazil, in a protracted crisis amid the COVID-19 pandemic, we predict that similar hurdles may produce similar challenges in this country.

Promisingly, Brazil is one of the few countries with a Statelessness Determination Procedure ('SDP'), established as a part of its 2017 New Immigration Law. ${ }^{34}$ Indeed, famous stateless activist Maha Mamo recently gained Brazilian citizenship after she was formally recognised as stateless under this new SDP. ${ }^{35} \mathrm{We}$ expect that the possibility of statelessness may increase due to the uncertainty of status and increased immobility that many Venezuelan refugees face during the pandemic in Brazil. However, a functioning SDP at least offers a channel of remedy in case they find themselves in need of status determination.

\section{CONCLUSION}

Our research has found that the circumstances during the COVID-19 pandemic in Brazil, greatly aggravated by a poor public policy response, has made Venezuelan LGBTQI+ asylum seekers and undocumented migrants especially vulnerable. The elimination of their livelihoods, uncertainty around their legal status, and the discrimination and violence they face highlight the dangers of 'politically produced precarity' and 'overlapping precarity'. ${ }^{36}$ Furthermore, there is a raised risk of statelessness. Since producing documentation becomes difficult in displacement, which has been compounded by the stagnation of bureaucratic processes during the COVID-19 pandemic, we also point to this real possibility of statelessness that deserves further exploration.

Ultimately, there needs to be better coordination between the Brazilian and international and local organisations working with asylum seekers and undocumented migrants. Reports indicate that if borders re-open in 2021, an additional 1.6 million Venezuelans will leave the country. ${ }^{37}$ This exodus will add

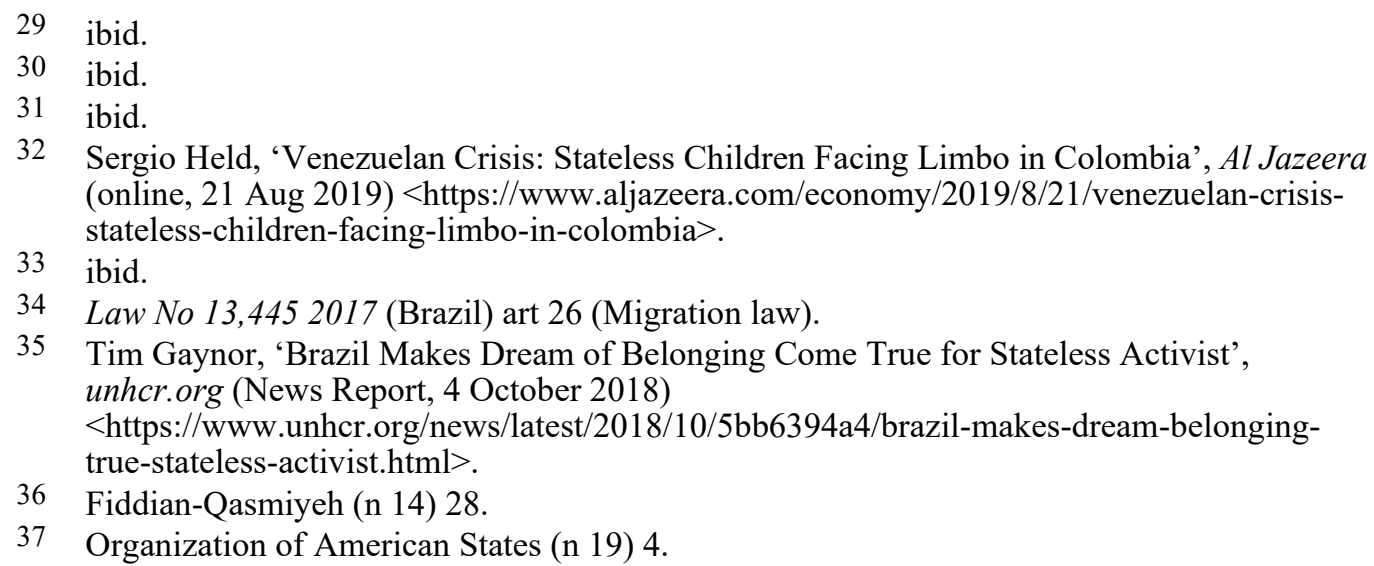


a tremendous amount of stress to an already burgeoning humanitarian crisis at the border, during what is labelled as the largest human tragedy in Brazilian history. ${ }^{38}$ Moreover, as the pandemic is continuously prolonged, especially with the emergence of variants, these overlapping precarities have only exacerbated.

38 'Covid: Brazil has More than 4,000 Deaths in 24 Hours for First Time', $B B C$ (online, 7 April 2021) <https://www.bbc.com/news/amp/world-latin-america56657818 ?_twitter_impression=true $>$. 